\title{
Seapower, geostrategic relations, and islandness: The World War II Destroyers for Bases deal
}

\author{
Colin Flint \\ Department of Political Science, Utah State University, USA \\ colin.flint@usu.edu
}

\begin{abstract}
The Destroyers for Bases deal was signed on March 27, 1941, and transferred fifty aging US destroyers to Great Britain in exchange for 99-year leases of bases on the British controlled islands of Newfoundland, Bermuda, Trinidad, Jamaica, Antigua, St. Lucia, the Bahamas, and one in British Guiana. The deal highlights how US strategic planners came to see the value of the islands because of their relationality. Three forms of relationality are discussed: the land/sea dialectic; spatial connectivity; and the changing geopolitical balance of power. Relationality is a factor in four strategic calculations: other islands; other continents; other oceans; and the conjuncture of long-term historical processes of hegemonic decline and rise. The relationality of the islands is understood through the lens of seapower as both input (the military bases) and output (the projection of force). Media representations of the deal are discussed to illustrate how islandness was implicit in the narration of the islands as being of strategic benefit to the US. The conclusions drawn emphasize the need to see strategic and military actors as agents who are aware of and construct island relationality; and the need for islands to be included as one of the inputs of seapower.
\end{abstract}

Keywords: Destroyers for Bases deal, islandness, seapower, United States of America, World War II

https://doi.org/10.24043/isj.139 • Received February 2020, accepted August 2020

(C) 2020 - Institute of Island Studies, University of Prince Edward Island, Canada.

A cardinal factor has naturally been that no strong naval power should be in effective permanent occupation of any territory or harbor east of Malta, if such harbour be capable of transformation into a fortified naval base. None can foresee the developments of material in warfare, and the occupation of the apparently most useless island should be resisted equally with the occupation of the best. The geographical situation of these islands enable the sovereign power, if enjoying the possession of a navy, to exercise a control over the Levant and Black Sea trade and to threaten our position in Egypt.

- Rear-Admiral Ernest Troubridge, the Chief of the War Staff of the British Admiralty, in a 1912 memorandum on the Italian occupation of some of the Turkish Aegean Islands (qtd. in Black, 2016, p. 119). 
Rear-Admiral Troubridge was very clear that any island, no matter how seemingly insignificant, enabled the building of strategic relations and contexts far beyond its immediate horizon. He was seeing, and trying to put into practice, the relationality of islands for the perceived benefit of British national security. Contemporary academics have created knowledge that islands are expressions of connectivity rather than isolation, with an eye to a progressive agenda of illuminating social fluidity and hybridity (DeLoughrey, 2001, p. 23). Ironically, national security strategists have been aware of the relationality of islands for a long time, though with a different political agenda. They have constructed islands as territorial entities enabling force projection, such that an island is not to be controlled by the military for the island itself, but because of its situation within a web of strategic relations and the ability to affect those relations. This paper attempts to further our understanding of the strategic relationality of islands, or islandness, by examining the case of the World War II Destroyers for Bases deal.

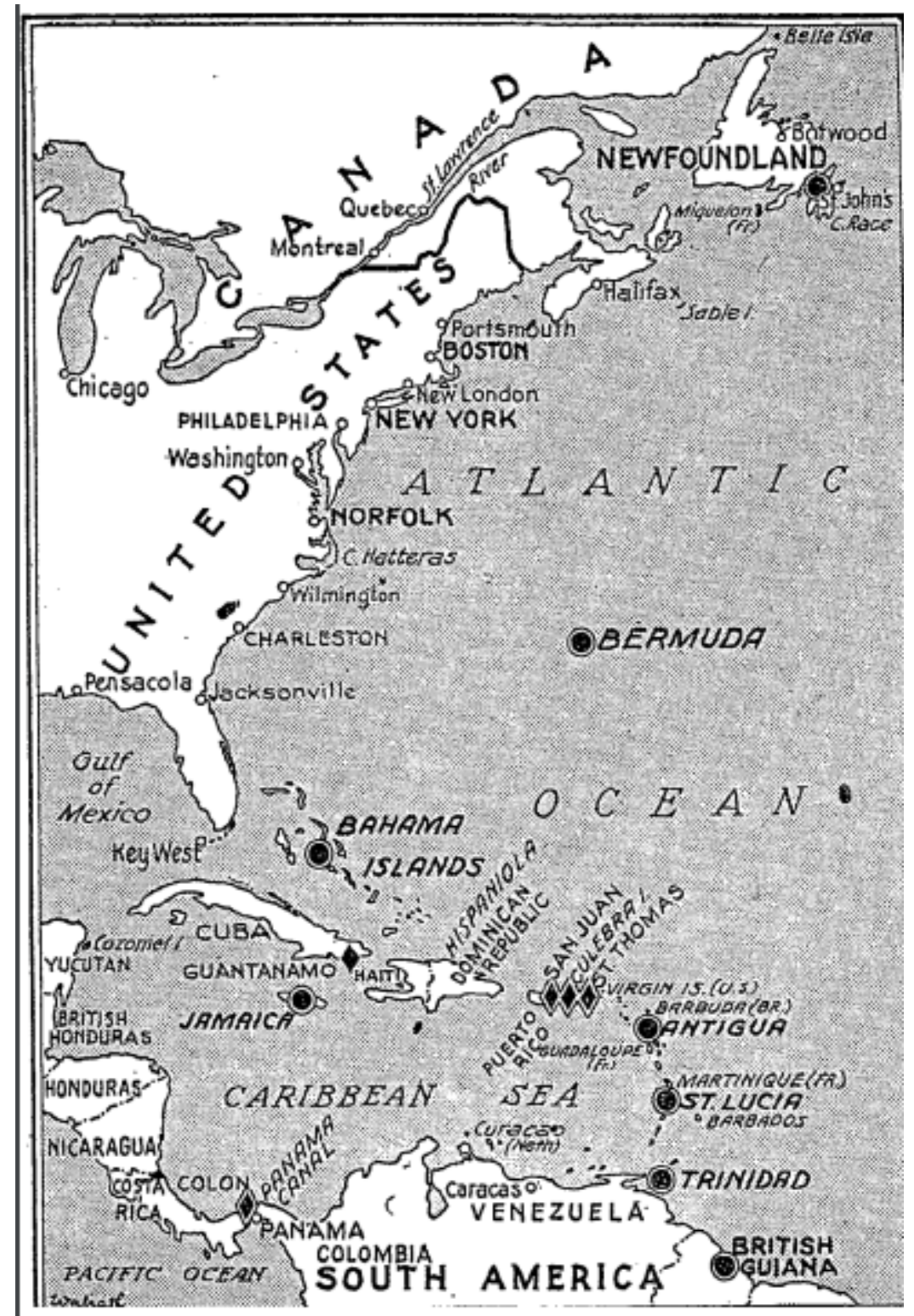

UNITED STATES ACQUIRES DEFENSE BASTIONS

Figure 1: The islands of the Destroyers for Bases deal. Source: Kluckhohn, 1940b, 1. 
As World War II raged in Europe, US strategists had begun to "think with islands" (to paraphrase Pugh, 2013, p. 20). Islands were seen within the perceived need for competitive control over the oceans (Steinberg, 2001; Steinberg \& Peters, 2015). One such set of islands were those seen as essential in the defense of the Eastern or Atlantic flank of the United States. Newfoundland, Bermuda, Trinidad, Jamaica, Antigua, St. Lucia, and the Bahamas, plus British Guiana, were British colonial possessions, and contained bases with naval and air capabilities (see Figure 1). These bases became the focus of strategy and politics because of their position within a web of strategic relationships that were concentrated on a continent, Europe, and another ocean, the Pacific. After political negotiation, the bases were leased to the US in return for the gift of fifty destroyers to the Royal Navy. The transfer of control became imperative at a moment in conjoined geopolitical processes of British hegemonic decline, US hegemonic rise, and the challenges to both countries by the Axis powers.

The strategic relationality of islands is a function of their physical reality of territory within oceans, that enables a material presence that can be projected beyond the horizon. Islands become essential calculations within projects of seapower. The twin aspects of territoriality and projection of islands reflect the notion of seapower as input and output (Till, 2013, p. 25). Islands are a geographic component of the inputs of seapower that Till $(2013$, p. 25) lists only as military capabilities such as navies, air forces, and coastguards. Islands add to these capabilities by acting as the locations for bases. The outputs of seapower are "the capacity to influence the behavior of other people or things by what one does at or from the sea" (Till, 2013 , p. 25). Control of islands enable states to use the sea as a "medium of dominion" (Till, 2013, p. 6), but the power effect comes from the relationality of seapower as output.

The example of the Destroyers for Bases deal illustrates that seapower inputs and outputs are best seen as interrelated moments in a geopolitical process rather than distinct categories. Outputs enable new inputs that in turn enable new expressions of output. The control of islands and the siting of bases enables force projection, or output, that maintains control of those islands and the acquisition of new ones, as inputs. Geopolitical competition is the driving process behind conflict over the control of islands. The outcome of that competitive process is partially decided by the fluctuation in the ability of competing states to maintain control of islands they currently count as inputs in the face of the ability of other states to use their current outputs to wrestle control of islands. Islands, as inputs and outputs, are valuable - and sought after - elements in the ledger of the balance of seapower. Their value is best understood through a relational frame that sees calculations regarding islands in specific seas and oceans within a global geopolitical imagination.

The islands in the Destroyers for Bases deal were seen as enabling a strategy of seapower output that was deemed necessary because of the continental concerns of Germany's control of Europe and the consequent threat to North America. The islands were in a web of strategic relations that saw the Atlantic as a contested dominion between two continents. The islands were to play a role as seapower inputs because of their situation relative to the "enemy's territory" (Corbett, 1988/1911, p. 14 and what their fleet could make it possible for their army to do. However, as complex as this set of relations was, it was not the full gamut of the strategic relationality. The perceived need of the US to add the islands to their seapower inputs was based upon evaluations of the military balance in the Pacific Ocean. Furthermore, these strategic relations can only be understood within the dynamic of US-British relations that were changing with long-term historical processes of their respective rise and declines as global powers. 
Specifically, two avenues of inquiry will be undertaken:

- An exploration of how the US strategic community in the 1930 s envisioned islands in a relational manner; highlighting the relationality of islands in the realm of strategic agency.

- An examination of how strategic relationality is multi-faceted, partly because of what we now understand as islandness and its connection to seapower; highlighting the particular role of islands within the construction of strategy.

The analysis leads to the conclusion that islands are important to powerful countries and their projection of seapower because of four strategic or geopolitical considerations: other islands; other oceans; other continents; and the processes of hegemonic rise and fall.

The paper begins with the conceptual foundations of island studies that make for a critical analysis of the islandness of strategy and suggests some necessary points of emphasis. Second, the strategic relations of the islands in question are discussed. Third, a brief synopsis of the Destroyers for Bases deal is offered. Fourth, the role of islandness in media representations of the deal are highlighted. The conclusion suggests some implications for island studies.

\section{Conceptual foundations}

The relational nature of islands has become axiomatic in island studies (DeLoughrey, 2001; Grydehøj, 2019; Grydehøj \& Hayward, 2014; Pugh, 2016; Stratford et al., 2011). The dialectical nature of the word 'islands' combines a sense of insularity and connectivity, so that its meaning is fluid or unstable (Shell, 2014, p. 20). The Norse meaning of island as "waterland" suggests a necessarily relational understanding of islands that interacts with an imperial worldview that islands are to be possessed and controlled (Shell, 2014, p. 18; WeaverHightower, 2007, p. ix). The instability of the term island is evident in its mobilization within geopolitical representations. In a speech at Lewes on 26 February 1896, the First Lord of the Admiralty Lord Goschen created a sense of insularity to justify a British foreign policy of "splendid isolation" (qtd. in Lee, 1994, pp. 256-257). In 1943, a particular islandness was deemed part of American exceptionalism the United States; an "island hemisphere" that needed to generate an island mentality as "the people that feels itself an island, because it is vulnerable, becomes aggressive" (Waldo, 1943, p. 520). In other words, the ability of seeing oneself as an island nation has been mobilized to create a sense of nationhood with a particular geopolitical vision and strategic role (Dijkink, 1996).

With the idea of relationality firmly established in the literature, this paper attempts to explore islands as "geostrategic sites of military intervention" (Mountz, 2015, p. 637; Davis, 2011; Davis et al., 2020) that give insights in to political geographies of hegemony (Mountz, 2015, p. 643; Davis, 2017). The control of islands as a strategic calculation for declining and rising powers gives emphasis to the role of core-periphery relations in geopolitics, rather than the limited focus of classic geopolitics upon great power relations. The peripherality of some islands, identified as a key component of the relationality of islands, becomes a key element of the geopolitical calculations of external and stronger powers due to their role in enabling 
the projection of power (Favole \& Giordana, 2018; Grydehøj \& Casagrande, 2019; Grydehøj \& Hayward, 2014; Petzold \& Ratter, 2019). In the Destroyers for Bases deal, US strategists constructed a set of "transoceanic imaginaries" (Stratford, 2013, p. 4) in which islands played a central role. The ability for these imaginaries to resonate with military strategists, politicians, and the public was a matter of the geopolitical narratives of the time, a temporal context of great power competition. The decline of Great Britain reduced its hold on colonial possessions, and simultaneously the increased power of the US led to its ability to take control of bases on these islands.

As Pugh (2018, p. 97) notes, the emphasis on the spatial relations of islands has not been sufficiently situated within temporal dynamics. Emphasizing the space-time dynamics of the relationality of islands requires a theorization of the geopolitical contexts within which dynamic island relations are constructed and contested (Grydehøj, 2019). The Destroyers for Bases deal can be situated within the dynamics of hegemony, specifically the related processes of Britain's decline and the emerging role of the US. The role of islands will alter over time as hegemony is a process with changing policies, needs, and abilities towards islands (Clegg, 2018; Pöllath, 2018). Across moments in the process of hegemony, islands remain "relational spaces" (Stratford, 2003, p. 495) with various expressions of regional and global connectivity (Baldacchino, 2006). Conflict is one set of social processes in which islands are evaluated and represented as strategic assets (Grohse, 2013; Kang, 2011).

In sum, island relationality may be seen in three related ways. First, the land/sea dialectic (Shell, 2014) recognizes the distinctive physical nature of islands as they bridge or deny a simple binary between continental and oceanic geopolitics. Second, the nature of islands enables and promotes spatial connectivity so that seemingly separate political developments in separate places are intertwined (DeLoughrey, 2001). Third, the competition for the control of islands is a component of the relationality of the process of shifts in the balance of power (Davis, 2017; Grydehøj, 2019; Mountz, 2015, p. 643). These three forms of island relationality are connected in a triangle of blended relationality in which the connections are power relations that are the simultaneous inputs and outputs of seapower (Till, 2013; see Figure 2).

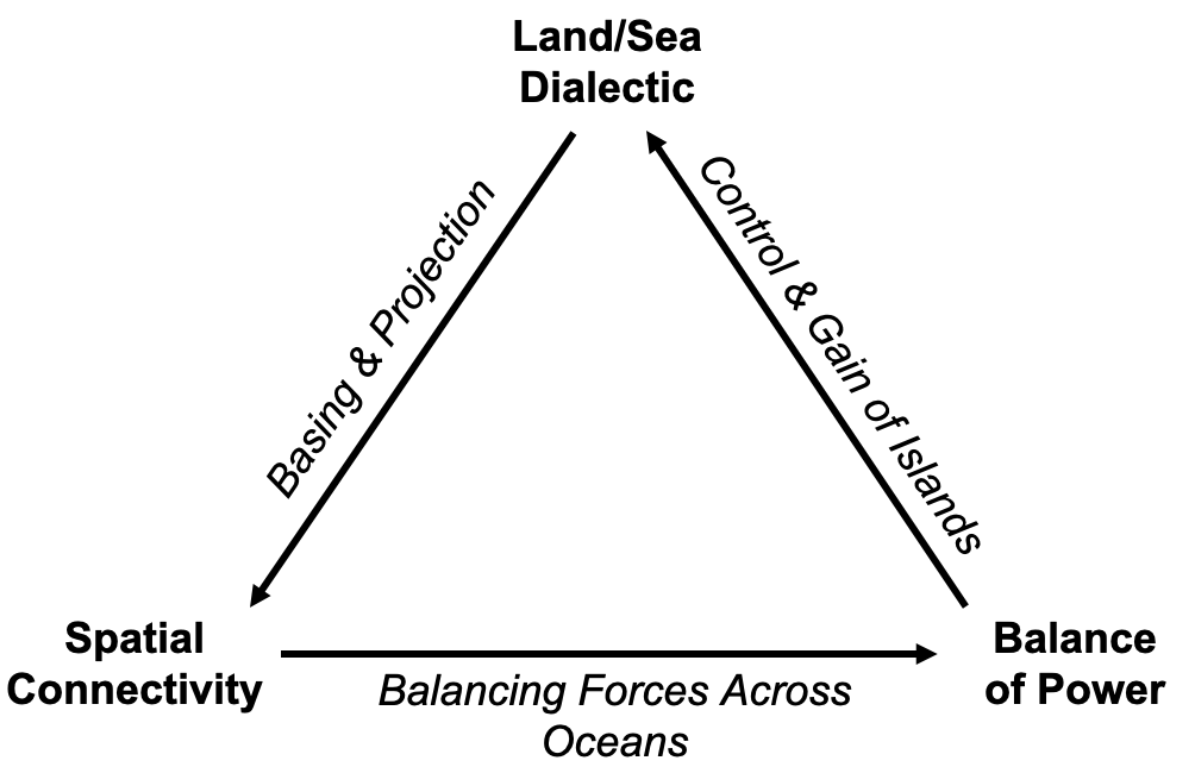

Figure 2: Island relationality and seapower. (C) Colin Flint, 2020. 
The land/sea dialectic of islands provides their physical value as the sites of military bases (inputs) that provide for force projection (output). Force projection enables spatial connectivity, a combined form of input and output depending on whether it is seen as an ability or an outcome. In turn, spatial connectivity changes the balance of power across oceans as strategists deploy their military capacity in a combination of defensive and offensive calculations that are enabled and driven by the control of particular islands by themselves or allies or foes. Deployment is both an input, as material capability, and output, as geopolitical outcome. Relative success in controlling islands is an important element in the process of the changing balance of power. As the balance of power changes, the possession of military might (input) will affect the relative ability of competing states to retain (input) and gain (output) control of islands, that are deemed geopolitically significant because of the land/sea dialectic and spatial connectivity forms of relationality.

In the instance of the Destroyers for Bases deal, hegemonic competition was the context within which islands were strategically evaluated, and control of these islands was a means to alter the competitive dynamics.

\section{The geostrategic relations of the islands}

Why did the islands included in the Destroyers for Bases deal become so important within US strategic calculations? The answer was island relationality in its three forms and four geopolitical calculations: other islands; other oceans; other continents; and the process of changing relationalities. These three forms of relationality interacted with islands as both inputs and outputs of seapower (Till, 2013, p. 25) in a geopolitical process that is heuristically summarized in Figure 2.

The process of the strategic control of the islands was rooted in the historical trajectory of the relative decline of Britain as a global power, and the rise of the US. The British Foreign Office had held concerns that British decline would lead to decolonization and losing Caribbean island colonies to the US and Latin American republics (Whitham, 2013). The Foreign Office had been working to negate the possibility of the British losing the bases to the US in "some unsatisfactory 'deal"” (Whitham, 2013, p. 234), but the relative trajectories of British and US power, magnified by the war, led to the deal. The peripherality of the islands meant that they could be discussed as bargaining chips within the strategic calculations of two seapowers, and, in this geopolitical context, there was little that the residents could do about it (Baptiste, 1976; High, 2009; Whitham, 2013).

The importance of the islands was not inevitable or even obvious even a few years before the deal was signed. Picking any starting point in this particular geopolitical process is somewhat arbitrary. However, a clear sequence of events began after World War I, and it began with other islands. Germany's defeat led to the islands of the Central Pacific they once controlled being mandated to Japan. The result was that Japan now controlled territory close to sea lines of communication (SLOCs) vital to the US (Morton, 1949, p. 22). The potential for Japan to be able to project power from these islands and disrupt SLOCs deemed vital to the US resulted in the 1924 US War Plan Orange which envisioned an offensive war with Japan. Subsequent analyses questioned the ability of the US to defend the Philippines. The final 1938 version of War Plan Orange adopted a "strategic triangle, Alaska-Hawaii-Panama" as the "peace-time frontier" (Morton, 1949, p. 24). The relationality of the Central Pacific 
islands was clear in their duality as territories that enabled reach across circumscribed parts of the oceans that had material value as SLOCs, and were, therefore, socially constructed as being of strategic value. This expression of islandness was central to US strategic thinking that, for a relatively short time, focused upon Japan.

Before War Plan Orange, US war planning was based on the premise of a "defensive war" (Watson, 1950, p. 29). However, this defensiveness was very extra-territorial in its expression. It contained calls for a strong navy to project force in the Pacific, and the ability to protect Latin American countries from aggression by European (i.e., German and Italian) countries (Watson, 1950, p. 86). The emergence of extra-territorial thinking was evident in President Roosevelt's October 1937 “quarantine speech" in which he saw the potential of war to spread, including into the Western Hemisphere. Ongoing conflicts were represented as a diffusing disease:

If those things come to pass in other parts of the world, let no one imagine that America will escape, that America may expect mercy, that this Western Hemisphere will not be attacked and that it will continue tranquilly and peacefully to carry on the ethics and the arts of civilization. (Miller Center, 2019)

Defending the country now required defending the Hemisphere, and defending the Hemisphere required global engagement. Roosevelt argued:

We are determined to keep out of war, yet we cannot insure ourselves against the disastrous effects of war and the dangers of involvement. We are adopting such measures as will minimize our risk of involvement, but we cannot have complete protection in a world of disorder in which confidence and security have broken down. (Miller Center, 2019)

A policy that blurred territorial defense with extra-territorial actions required a fuzzy geographic understanding of the Western Hemisphere (Kimball, 1997, p. 74), but would still require a concrete military presence to project military force.

In January 1938, US and Britain came to an agreement "which provided mutual assurance that waters of the British Commonwealth would be available for U.S. vessels and U.S. waters would be available for British vessels" (Watson, 1950, p. 93) to combat the Japanese. At this time, Japan was the focus of US strategy and, despite tentative talks regarding the use of the Caribbean bases by US forces, in May 1940 US limitations in patrolling the Atlantic were clear as result of its commitment in the Pacific (Hall, 1955, p. 142). The emerging combination of territorial defense and force projection led to the expansion of the geostrategic scope of the US, and the web of relationality became more complex. Strategic concerns over military control of one continent generated strategic relational thinking about islands bordering another. The question of Europe promoted the strategic value of islands off the North American coastline.

These changes reflected the realization that the US did not have the military capability to wage an offensive war against Japan in the Pacific while also addressing hemispheric and Atlantic concerns. Focus moved from Pacific to Atlantic islands. The Philippines, Guam, and Wake were effectively abandoned. Hawai'i, the Panama Canal Zone, and the Caribbean 
became more important. The geostrategic drivers - and, therefore, calculations - had changed completely. From the perceived Japanese threat to SLOCs, Germany's ability to control the European continent became the imperative. And with this shift came the re-orientation from national defense to hemispheric defense; a shift that relied upon not just the US obtaining island bases, but the particular form of islandness that entailed. Namely, the territorial nature of islands allowing them to be bases to project across the ocean, simultaneously acting as an input and output of seapower (Till, 2013, p. 25).

The process of replacing national defense with hemispheric defense led to the recalculation of the strategic value of the Caribbean. In February 1939, a US War Planning Department memo had raised the specter of Germany and Italy violating the tenets of the Monroe Doctrine: "Before military force replaces diplomatic negotiations, hostile nations may be firmly established in the Western hemisphere in areas that threaten not only our national interests, but such vital areas as the Panama Canal as well” (Watson, 1950, p. 102). The flux of strategic relationality was becoming evident: defensive postures in the Pacific and the Western Hemisphere, treated separately, were no longer adequate - and the focus on the Panama Canal illustrated how the Atlantic and Pacific theaters had become related.

The General Staff re-calculated their role and duty in the light of German, Italian, and Japanese military aggression, and combined a geographical shift from national defense to hemispheric defense with a change in posture:

Under the policy of hemisphere defense we [General Staff] have formulated for the Army a new mission that recognizes the importance of the initiative in war and visualizes an early need for more than passive defense. Under this policy we have set our mission as the defense of not our territory alone, but cooperation in the defense of the entire western hemisphere. This mission requires the provision of means with which we can deny the enemy bases from which he might launch military operations against us or any of the democratic nations of this hemisphere. This policy is designed to reduce to a minimum the likelihood of accepting a war upon our own territory. (Unsigned memo of 1 November, 1939, sent to the War Planning Department (reference 4175-2), qtd. in Watson, 1950, pp. 88-89)

The posture change from passive defense to dynamic defense created a geography of seeking, ultimately, power projection in the Pacific Ocean that created a parallel geographic imperative of securing a loosely defined Western Hemisphere (Watson, 1950, pp. 95, 102).

Force projection in the Pacific was a strategic concern for both Britain and the US, with concern over Japan's intentions (Matloff \& Snell, 1999/1953, pp. 76-78). However, the two countries had different interests and commitments. From its perspective, the United States, although it had assumed great military obligations in the Far East, had assumed them independently and on terms that virtually precluded close collaboration between the British and American military staffs (Matloff \& Snell, 1999/1953, p. 78). These differences were soon to be reconciled in a way that placed the islands of the western Atlantic at the center of strategic calculations. Questions over the defensibility of the Philippines, Guam, and Wake, coupled with the continental victories of Nazi Germany, placed the Caribbean and the Canadian seaboard at the heart of calculations. 
The decision-making process that identified the new strategic imperatives and made them into policy was the creation and revision of the Rainbow war plans. In the 1920s, the US had developed separate war plans for operations against singular enemies (i.e., Japan was war plan Orange). In 1938, Germany's annexation of Austria and occupation of the Sudetenland led to the recognition that existing separate war plans were inadequate, and that the Rainbow plans were necessary. The Rainbow plans were written in 1939 and were originally a combined set of plans to reflect the inter-connected nature of future theaters of war (Matloff \& Snell, 1999/1953, p. 6). The plans were built upon "the realistic assumption that the United States might become involved in a war with more than one enemy and in the Atlantic as well as the Pacific" (Morton, 1949, p. 28). The strategic connection of the Pacific and Atlantic oceans was an outcome of the changing roles of the US and Britain; a historical conjuncture of two different geopolitical trends. Britain's decline in power was ongoing, but they still had substantial interests in the Pacific region and, significantly, were perceived to be able to defend them. The US was a rising global power, and still relied on the capabilities of Britain, and other countries, to meet security imperatives that involved two oceans, and the question of who controlled the European continent. The Rainbow plans were constructed to try and integrate these different geographic imperatives and perceptions of power projection. The ability to enact such integration raised the question of the military control and use of the islands to be included in the deal.

Rainbow 1 was seemingly focused on the Western Hemisphere, retaining the understanding of the Monroe Doctrine, and its current manifestation under President Roosevelt's "good neighbor policy," and the defense of the US homeland. However, notable is the relational focus of the plan. The aim of the plan was to protect the territory of Latin American countries "while protecting the of the United States, its possessions and its seaborne trade" (Matloff \& Snell, 1999/1953, p. 7). This part of Rainbow 1, referred to as "a" in the subsequent plans, proclaimed the understandable goal of defending the territory of the US. However, the territory of the US and the countries of Central America and northern South America was identified as being strategically important not just to secure the homeland, but to enable global economic networks based on ocean trade. In combination, the Rainbow plans defined US security interests as domestic and territorial and, simultaneously, global, networked, and trade oriented.

The twin security of concerns of territorial defense and global economic reach also required the key matter of avoiding war in Europe. Rainbow 2 identified the desire of the US to avoid a military commitment to the European continent while supporting the interests of Great Britain, France, and other "Democratic Powers in the Pacific [...] and to defeat enemy forces in the Pacific" (Matloff \& Snell, 1999/1953, p. 8). Rainbow 3 recognized the importance of securing US interests in the Western Pacific (Matloff \& Snell, 1999/1953, p. 7). Rainbow plan 4 made explicit the need for "projecting such U.S. Army Forces as necessary to the southern part of the South American continent or to the Eastern Atlantic." Such force projection was deemed necessary to enable the protection of the US and the area identified in Rainbow plan 1 "the Western Hemisphere north of the approximate latitude ten degrees south" and SLOCs (Matloff \& Snell, 1999/1953, p. 7). In Rainbow plans 1-4 some form of force projection was seen as potentially necessary, to secure US territory and its trade networks, but that projection was to be limited. 
The possibility that hemispheric force projection would not be enough was outlined in the last of the plans. Rainbow plan 5 was the boldest step for the US, and the one it wanted to avoid. In order to protect the Western Hemisphere and the territory of the US the plan enabled the military to:

project the armed forces of the United States to the Eastern Atlantic and to either or both of the African or European Continents, as rapidly as possible consistent with carrying out the missions in a above, in order to effect the decisive defeat of Germany, or Italy, or both. This plan will assume concerted action between the United States, Great Britain, and France. (Matloff \& Snell, 1999/1953, p. 8)

Rainbow plan 5 acknowledged that the territorial security of the US was dependent upon friendly countries controlling the Atlantic. Though not explicit in the plan, the broader set of calculations was based on the foundation that the US presence in the Pacific, and the protection of its economic interests and potential in the Eastern Hemisphere, was dependent on being safe from attack across the Atlantic. The islands in the Destroyers for Bases deal were coming in to focus for US strategists because of power projection calculations in another ocean, the Pacific.

Changing circumstances led to the abandonment of these plans, and the sole relevance of Rainbow 5. Rainbow 2 and 3 were formally abandoned in August 1941, because of the recognition of Germany as the principle enemy (Watson, 1950, p. 104). Numbers 1 and 4 were not formally cancelled until May 1942, but "much that they contemplated, such as the taking over of British bases (by the old-destroyer transfer of 3 September 1940) and the progressive use of Atlantic sea patrols, was in effect" (Watson, 1950, p. 104). The abandonment of Rainbow 1 and 4 was a result of an assumption not being met: Britain's navy forces had not been defeated and, therefore, the problem of hemispheric defense had been ameliorated (Watson, 1950, p. 104). On the other hand, the control of the European continent by Germany and Italy had promoted Rainbow 5 into the basic plan for US war readiness by the time of its formal entry into the war in December 1941.

The Axis victories in Europe dramatically changed US strategic thinking and made the Destroyers for Bases deal imperative. An unsigned memorandum received by the US Chief of Staffs on 21 May, 1940 stated: "In view of the present world conditions it is believed that this country should take immediate steps to acquire British and French possessions in the Atlantic" (Watson, 1950, p. 105). The developments in the Pacific and on the European continent combined in to a dynamic web of strategic relations that catalyzed a strategic recalculation of the relationality of the islands in the Destroyers for Bases deal.

As the prime concern of the US became the Western Hemisphere and territorial security, it came to rely on Great Britain and the Atlantic theater - at the same time that Britain saw its ability to secure itself from German aggression by maintaining its colonial relationships in Asia. Britain's status as a declining, but not defeated, power enabled it to project some power in the Pacific but not on the European continent. This provided both opportunities and concerns for US strategists. The spatiality of the web of island relations at the heart of the Destroyers for Bases deal was in flux because of the temporal context of declining British and emerging American hegemony (Mountz, 2015, p. 643). 
The web of relationality became focused on the role of Great Britain, and the question of its ability to project power in the Pacific and avoid defeat in Europe. In June 1940, the US strategy discussed the potential transfer of the Pacific fleet to the Atlantic (Watson, 1950, p. 110). There was also military concern over giving further war material to Britain, with the recognition that Britain may lose the fight anyway and that such material would be wasted, and hence the US would have great need for it. Roosevelt offered qualified support for retaining US war material, which was the precursor for allowing the release of the destroyers exchanged for the bases; for it was the bases that had risen in priority (Watson, 1950, p. 111). Hemispheric defense might now require, according to the Chiefs, "occupation of British, French, Dutch, and Danish possessions in the Western Hemisphere (including islands of Atlantic and Pacific) excepting always Canada and Newfoundland" (Watson, 1950, p. 111).

Japan was still seen as a threat, but in August 1940 the British admitted that they were unlikely to be able to defend Singapore if it meant weakening war efforts in the Atlantic and the Mediterranean (Watson, 1950, p. 114). In March 1941, the new American-British Conversation $(\mathrm{ABC})$ plans had seemingly connected the relationality into a logical web. The US's "paramount territorial interest was in the Western Hemisphere" (Watson, 1950, p. 376); British security was imperative and dependent upon the security of the British Commonwealth, especially its position in the Far East "such as will assure the cohesion and security of the British Commonwealth; and the security of sea communications" (Watson, 1950, p. 376). In September of the previous year, the US had recognized the essential importance of securing the Western Hemisphere, including control of Gibraltar, Dakar, the Azores, Canary, and Cape Verde Islands, as well as the western Atlantic (Watson, 1950, p. 116). Japan's sweeping victories in Indo-China would, in hindsight, illustrate that faith in Britain's military abilities in the Pacific theater, while fears of loss of its fleet to Germany were not realized.

The strategic web, including Britain's hoped-for role in the Pacific, was summed up by the Joint Planning Committee on 21 December 1940:

Our interests in the Far East are very important. It would, however, be incorrect to consider that they are as important to us as is the integrity of the Western Hemisphere, or as important as preventing the defeat of the British Commonwealth. The issues in the Orient will largely be determined in Europe. (Watson, 1950, p. 123, emphasis added)

The continent of Europe was connected to the defense of the US homeland. The role of the Atlantic Ocean in the defense of the US was connected to the ongoing, and future, questions of power projection in the Pacific. And the islands of the Pacific were to become key to subsequent military expansion, but only once the Western Hemisphere was deemed secure. The plan to obtain the islands of the Destroyers for Bases deal as inputs of seapower were situated with calculations of other continents, oceans, and islands as the output of seapower (Till, 2013, p. 25).

The Joint Planning Committee's connection of the desire to project power in the Pacific at a later date with the immediate need for hemispheric defense crystallized the thinking that led to the transfer of the bases in the Destroyers for Bases deal being identified as a strategic need. Perceived British strength in the Pacific and weakness in the Atlantic re- 
oriented US strategic calculations to the Atlantic, and the imperative for access to bases became a strategic need. The bases were a set of nodes in a web of strategic relations that connected German and Italian victories on the European continent, Japan's ambitions in Indo-China and the Pacific, shared US and British concerns over ocean trade routes, Britain's reliance on the Commonwealth (and the Far East in particular), and the symbiotic security relations being conjured up by the British and US military staff under the urging and guidance of President Roosevelt and Prime Minister Churchill.

\section{The Destroyers for Bases deal}

The Destroyers for Bases deal was a precursor to the broader Lend-Lease Agreements. The deal entailed an exchange of 50 US destroyers for 99-year leases on large military base locations in Newfoundland, Bermuda, Trinidad, Jamaica, Antigua, St. Lucia, and the Bahamas, and one in British Guiana (High, 2009, p. 1). The deal was a product of twin-needs. Britain had an immediate need for military equipment in the face of a possible invasion by Nazi Germany and its naval forces being stretched thin between the strategic imperatives of controlling home waters, protecting colonial interests in the Pacific and Indian Oceans, and ensuring connections across the Atlantic. The US had a strategic need to protect its Eastern flank amidst concerns over how to locate its naval forces in both the Pacific and the Atlantic.

The destroyers left much to be desired. They were Town class destroyers built by the US during World War I. Though based on existing British V class destroyers, the US design was different and, once in service, some serious deficiencies were exposed (Hague, 1990, p. 7). Namely, the location of the guns restricted the field of fire and caused instability, and the torpedo design made firing in choppy seas and at high speed difficult. Plus, there was a high degree of steering failure, even after the British were forced to renew all steering gear every three months (Hague, 1990, p. 7). If these deficiencies were not enough, the British discovered "by bitter experience and some loss of life" that the bridge was "quite incapable of withstanding severe winter weather in the North Atlantic" (Hague, 1990, p. 8). In sum, not an ideal ship for North Atlantic anti-submarine convoy duty.

The US had been eyeing the Caribbean basin as an arena of economic and military expansion through the 1800s. The ability of the US to gain influence in the region had been limited, compared to the rest of Central and South America, because of the strength of British naval power (Chester, 1980, p. 3). In the wake of World War I and the difficulties Britain had in paying back war debts, an annexationist movement emerged in the US to take control of Bermuda and the British West Indies (Chester, 1980, pp. 5-6). Despite the Prince of Wales claiming in a 1933 speech in Port-of-Spain, Trinidad, that "British subjects were not for sale," (Chester, 1980, p. 6) and continual protests by the Jamaican newspaper The Daily Gleaner, the twin processes of waxing and waning hegemony led to growing US political influence as the British became increasingly concerned with the likelihood of decolonization (Whitham, 2013).

The completion of the Destroyers for Bases deal was a protracted process requiring political patience and innovation because of political opposition to the entry of the US into the war and the legal restrictions of the Neutrality Acts. The strategic community, including President Roosevelt, believed that the control of the Western Hemisphere was essential for

the defense of the United States (Butler, 2004, p. 5). Intensification of discussions regarding the transfer of British bases was re-invigorated in 1939 (Baptiste, 1976). In July 1939, 
President Roosevelt, Secretary of State Cordell Hull, and the Chief of Naval Operations met with the British ambassador to the US and introduced the goal of initiating US patrols over the Western Atlantic "in order to deny those waters to belligerents" (Hall, 1955, p. 43). The first step was for the US to seek permission for the US Navy to allow its ships and aircraft to use the ports and waters of the colonies of Trinidad, St. Lucia, and Bermuda, and to lease premises and land stores. A similar approach was made to Canada regarding the use of the port of Halifax, Nova Scotia. On 17 July 1939, the British Government sent instructions to the Governors of the colonies about the agreement and, on the 25th of August, the British ambassador informed the governors of Bermuda and the Windward Islands that the agreement was to be out in motion. In effect, the US Navy was in control of the bases, the islands, and 300 miles out to sea from the Newfoundland Bank to the West Indies islands (Hall, 1955, p. 44). The space of control, though delineated in the agreement, was in practice vague and dynamic. Secretary of State Hull, in the 1939 Declaration of Panama, saw the new zone as being "flexible" allowing the US to "patrol out to sea whatever distance as might be necessary to protect our shoreline and territorial waters" (Hall, 1955, p. 44).

On 14 May 1940, the French premier made an inquiry regarding the US selling or lending some destroyers. Winston Churchill did the same thing the next day (Hague, 1990, p. 7). The defeat of France in June 1940 intensified the case for action as the British faced the possibility of invasion and the US saw the vulnerability of its western flank. In July, the British cabinet accepted the need for a Destroyers for Bases deal, though it had rejected something similar the month before (Hague, 1990, p. 7). However, the legal matter of the Neutrality Acts made the issue complicated, as did US fears that the destroyers would soon become German property if Britain was overrun (High, 2009, p. 24). On September 2nd, the British and US parties exchanged notes outlining the deal, and the next day the notes went to Congress. However, there was much diplomacy still to take place (High, 2009, p. 25). In late September, Lord Lothian, the British ambassador to the US, inquired whether the bases would remain available to the British military. He was rebuffed on the basis that Britain was a belligerent nation, and not located within the Western Hemisphere. The combined complications of domestic British and US politics, their bi-lateral relations, and the British relations with the colonies, meant that the Base Lease Agreement was not finally signed until March 27, 1941 (Baptiste, 1976, p. 5).

\section{Representing the new strategic islandness of the US}

As the US strategic planners were wrestling with their response to the changing geopolitical situation, President Roosevelt was worried how the deal would play out with the American electorate, and made sure that specific questions were placed in polls to evaluate opinion (Chester, 1980, p. 9; Heinrichs, 1988, p. 11; Shogan, 1995, p. 242). His worries were unfounded as the polls found strong public support, echoed by prominent newspapers such as the The New York Times and the New York Herald Tribune. The deal was also largely acclaimed by US politicians (Chester, 1980, p. 9). This representation even received support from isolationist politicians and newspapers, such as the Chicago Tribune (Shogan, 1995, p. 243); though overall the press in the Midwest were more skeptical (The New York Times, 1940a, 13). Opposition was focused on the allegation that the process leading to deal was undemocratic, and it would drag the US in to a relationship with Britain that would force it 
into another war (Shogan, 1995, p. 244). President Roosevelt was able to garner such support by focusing not on the destroyers but the bases (Shogan, 1995, p. 242).

The deal became accepted by the public and the political establishment because, along with a new strategic geography, there emerged new and parallel geopolitical representations to garner support for the changing strategic posture, and the likelihood of entry into the war. The media was the vehicle for conveying "information about places" (Dittmer, 2010, p. xvii) and broader geopolitical imaginations that connected a sense of self with one's country and its role in the world (Dijkink, 1996; Dittmer, 2010). The media, especially the influential opinion-making The New York Times, played a role in justifying the transaction to a nation with isolationist tendencies. In so doing, it emphasized the islands as defensive oriented inputs of seapower; though as the war progressed the fluid interpretation came to focus upon force projection, or the output of seapower (Till, 2013, p. 25).

A positive tone was produced by ignoring the gift (of the destroyers), or the loss of material assets, and focusing on the acquisition of the bases. In August 1940, media reports emphasized that President Roosevelt was denying that the destroyers were part of any deal (The New York Times, 1940b). The following month, the headlines expounded that "U.S. Seen as Gainer in Destroyer Deal" and "Help to Britain Limited" (Baldwin, 1940a, p. 14). While the transfer of the destroyers was being denied, expert voices were being marshaled to expound the value of the island bases. Retired Rear Admiral Yates Stirling, Jr., though eliding the truth of the growing geopolitical reach of the US over the previous decades, educated the public along the following lines: "A cardinal principle of sea power is that naval and air bases are key factors in naval strength. Until lately this country has neglected that principle" (Stirling, 1940, p. 4). The argument was an explanation for public consumption of the value of islandness for strategy and national defense:

Figuratively speaking, bases are spots from which to launch offensive weapons against an enemy. Once sent from the base, as projectiles, they can operate and steam or fly for a specific length of time, when they must return to a base for refueling and repairing of damage incurred through contact with an enemy... Thus we see, a lack of bases in any area prohibits effective operation in that area. (Stirling, 1940, p. 4)

The representational focus upon the islands rather than the destroyers illustrates that the inputs of seapower are somewhat interchangeable (Till, 2013, p. 25); ships can be gifted but that was, apparently, more than balanced by the acquisition of islands. In July 1940, a sober article in The New York Times emphasized the need for defensive inputs by informing its readers that German dominance in Europe could lead to control of Atlantic territories under the control of subjugated European countries, notably the Danish colony of Greenland and Dutch possessions in the Caribbean. The article went on to claim that:

in naval, military and aviation circles, it has long been recognized that the islands lying in this hemisphere offer bases for would-be aggressors and also for defense against attack. [...] If the Nazis should demand and receive the New World possessions of conquered European States, and particularly the islands off the shores of the Americas, it was suddenly widely believed, they would have a springboard for attack. (Kluckkohn, 1940a, p. 56) 
The emphasis upon the defensive benefits of the deal, and the sense that the US had done well out of the transaction, continued. The New York Times splashed the headline "Bases Pacts Give Us Large Powers in British Areas" (Reston, 1941).

Maps published in the media at this time emphasized the islands as "defense bastions" to avoid any sense of force projection, and the geographic scope focused on the Eastern seaboard of North America (see Figure 1). The maps were supported with a narrative that the islands were a form of defensive seapower input, preventing, rather than provoking, entry into the war:

These bases, extending from the sub-Arctic almost to the equator, bear witness to the fact that naval and military experts of the United States realize that the airplane and other modern inventions have indeed cut space and time. They offer physical evidence of the belief of minds trained to be responsible for this nation's safety that, in the hands of an enemy, the Atlantic could become an avenue for attack on the New World. (Kluckhohn, 1941, p. E5).

The media proclaimed that the deal would make it unlikely that the US would become further involved in the ongoing conflict. For example, The New York Times reported on discussions in the British media that the potential seizure of German, Italian, and Danish ships in US ports would not embroil the US as "Germany was unlikely to regard the action as an act of war since she already had had plenty of 'provocation' in the destroyers-for-bases deal and the passage of the lend-lease bill" (The New York Times, 1941, p. 8).

The focus upon defense required that the bases be portrayed as a new form of seapower input (Till, 2013, p. 25). However, as tensions with Japan rose, some articles began to describe the value of the islands in terms of seapower output, or offensive force projection (Till, 2013, p. 25). One article noted that "the Anglo-American destroyer-naval base agreement was part of the setting of a world in restless flux" (Baldwin, 1940b, p. 77). The intersection of the new air power with the continuing value of seapower was only feasible with territorial possessions, especially islands with their duality of solid ground as launching pad to reach across the oceans (Shell, 2014, p. 18). This idea was conveyed to the US public:

Just as secure bases are necessary for sea power, so, too, are such bases necessary for air power [...] the network of air fields of a great power must be so situated that you can bomb the enemy's vital centers better than he can bomb yours; it does mean that the source of supply for those air fields must be relatively secure from enemy bombing raids [...] It is obvious, therefore, with these principles in mind, why new air and naval bases are so important to any great power. (Baldwin, 1940b, p. 77)

Bombing was becoming just as important as being bombed as the islands were framed as a form of seapower output (Till, 2013, p. 25). A new focus appeared in media maps to support the new representation of the need and benefit of force projection. The islands now became the sources of airplanes and arrows pushing across the Atlantic (see Figure 3). 


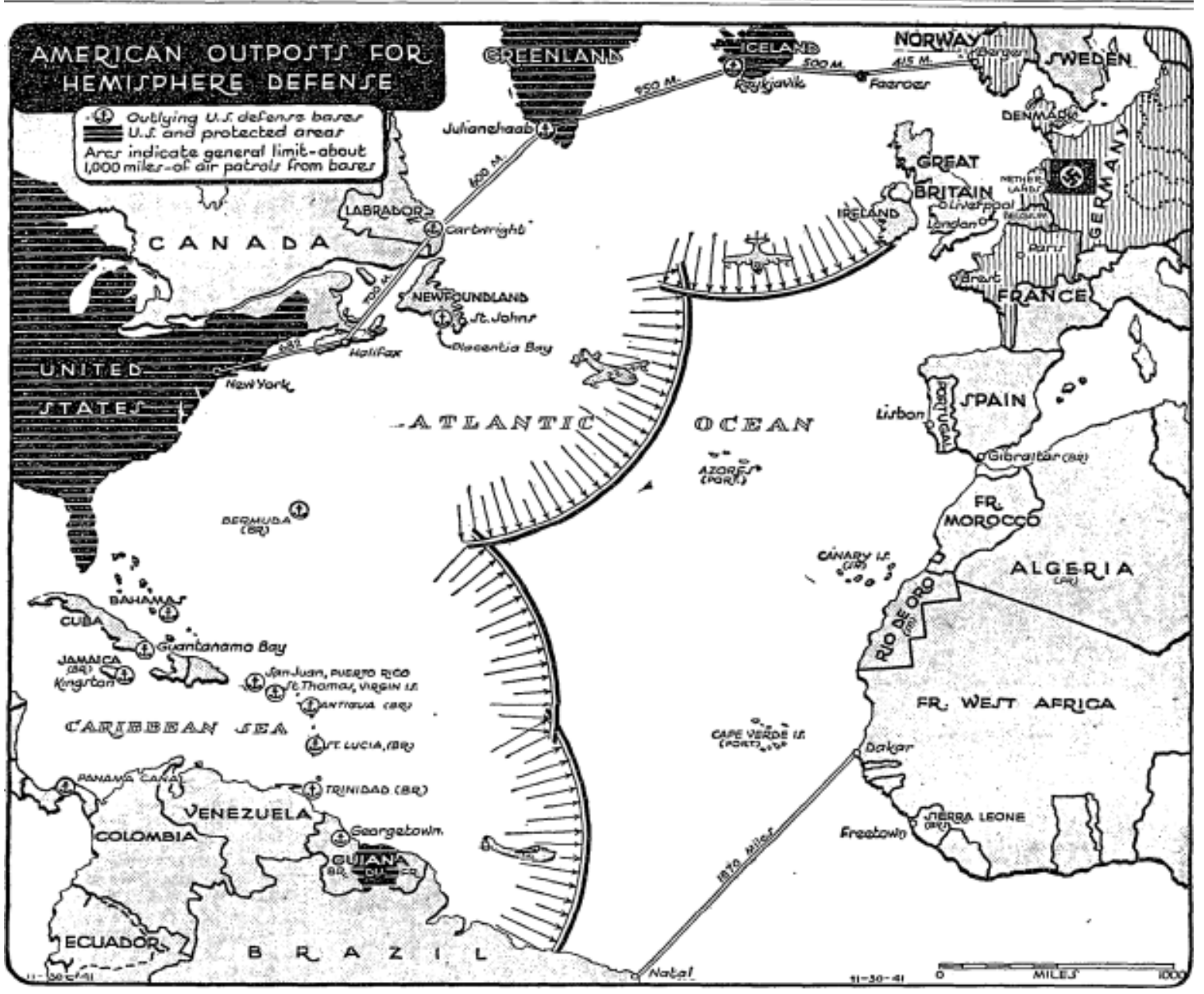

Figure 3: The islands as sources of force projection. Source: Kluckhohn, 1941, p. E5.

The conjunction of strategic calculations and practices with a parallel narrative in the media put the Destroyers for Bases deal at the center of US policy and public perception. The process was a construction of islandness that was as dynamic as the strategic context - and hence the value of the islands - changed. The processes of the respective rise and decline of US and British power meant that the situation of the islands remained important, but the nature of the relationality changed. The process of evaluating strategic islandness is ongoing, as a post-war trans-Atlanticism emerged (Kimball, 2013). The legacy of the Destroyers for Bases deal and the trans-Atlantic connections that were built through the war was seen in George Marshall's vision of NATO and the European Recovery Program (commonly called the Marshall Plan). These institutions were based on the strategic vision that the "vital interests of the US lay in the Atlantic and Europe, not Asia and the Pacific" (Stoler, 2013, p. 309). Stoler (2013, p. 309) goes on to define perceived value of force projection in the Atlantic in the belief "that the US could not successfully defend the western hemisphere against a hostile power in control of all Europe." The strategic need for the control of the islands of the western Atlantic and Caribbean continued to be seen in a relational manner, connected to the military control of the European continent. 


\section{Conclusion}

The historical focus of this paper was the early years of World War II, but it began with a quote from before World War I. The theoretical discussion of island relationality that the Destroyers for Bases deal illustrates is also relevant to contemporary world politics. For example, the US Department of Defense perceives that the islands of the South China Sea are strategically important because of their relationality with regard to the Indian Ocean, as well as growing Chinese involvement in Africa and Eurasia (US Department of Defense, 2019). The strategic relationality of islands is pervasive across time because islandness is a component of seapower as input and output (Till, 2013, p. 25). Specifically, island relationality has been shown to be important in four strategic calculations and military actions: relationality with other islands; relationality with other oceans; relationality with continents; and the relationality of particular historical moments as the conjuncture of the power trajectories of competing and collaborating states.

One conclusion that may be drawn from the example of the Destroyers for Bases deal is that strategists are a set of actors that understand the mutual construction of space and politics. That is not to say they are geographic scholars and readily adopt the tenets of contemporary human geography theory; their understanding of the social construction of spaces is practical rather than theoretic. Island studies scholars need to include the perceptions, calculations, and actions of military strategists as forces creating the dynamism of island relations. In addition to the critical engagement of the military use of islands (e.g., Davis, 2017; High, 2009), our analyses can also focus on the particular forms of relationality that strategists perceive and attempt to alter.

Furthermore, in certain cases, such as the Destroyers for Bases deal and, arguably, developing issues in the South China Sea, the scope of such relationality becomes global, requiring a framework that looks at the global scale and includes long historical processes. As island studies needs to consider the strategy of states as a form of islandness and relationality, it is hoped that there would develop a reciprocal recognition of not just islands, but the role islandness, in strategic understandings of seapower. The Destroyers for Bases deal highlighted the role of islands as inputs and outputs of seapower, but it is a stark omission for Till (2013, p. 25) not to include islands themselves in his list of inputs. It is their very nature, the simultaneous role as pieces of territory that may house military forces and as launching pads of force projection as they are surrounded by sea, that makes islands a hybrid of seapower inputs and outputs. Hence, islands are simultaneously valuable inputs and outputs in geopolitics as ongoing process in which controlling and using islands are intertwined means and goals of inter-state competition (see Figure 2). It is the relationality of islands as a land/sea dialectic, a form of spatial connectivity, and a factor in hegemonic competition that gives them value as seapower inputs and targets of geopolitical ambitions.

The critical engagement of the military use and abuse of islands has largely focused on the activities and assemblages within the islands themselves and the relationality of resistance (see Davis, 2011, 2017). This valuable work may be complemented by situating those islands in broader geographic and historical scopes of relationality. Theorizations of the historical dynamics that create relationalities and are further shaped and transformed by those relationalities are an important element of island studies (Pugh, 2018, p. 97). As Mountz (2015, p. 643) notes, the temporal dynamics of inter-state competition is one set of rhythms 
of island relationality. When hegemonic powers are the key actors in defining an island's relationality, we must consider other continents, other oceans, and other islands within the compass of relations.

\section{Acknowledgments}

I would like to thank Jaclyn Caldwell and Lauren Pack for their sterling research endeavors, the two reviewers for their very helpful and supportive comments, and Adam Grydehøj for shepherding the paper through the process.

\section{References}

Baldacchino, G. (2006). Islands, island studies, island studies journal. Island Studies Journal, 1(1), 3-18.

Baldwin, H.W. (1940a, September 4). U.S. seen as gainer in destroyer deal. The New York Times, 14.

Baldwin, H.W. (1940b, September 8). Our deal with Britain affects a world's strategical picture. The New York Times, 77.

Baptiste, F.A. (1976). The British grant of air and naval facilities to the United States in Trinidad, St. Lucia and Bermuda in 1939 (June-December). Caribbean Studies, 16(2): $5-43$.

Black, J. (2016). Geopolitics and the quest for dominance. University of Indiana Press.

Butler, P. (with Hagedom, D.). (2004). Air arsenal North America: aircraft for the Allies 19381945. Midland Publishing.

Chester, E.W. (1980). The United States and six Atlantic outposts: The military and economic considerations. Kennikat Press.

Clegg, P. (2018). The United Kingdom and its overseas territories: No longer a 'benevolent patron'? Small States \& Territories, 1(2), 149-168.

Corbett, J. (1988). Some principles of maritime strategy (2nd ed.). Naval Institute Press. (Original work published 1911)

Davis, S. (2017). Apparatuses of occupation: Translocal social movements, states and the archipelagic spatialities of power. Transactions of the Institute of British Geographers, 42(1), 110-122. https://doi.org/10.1111/tran.12152

Davis, S. (2011). The US military base network and contemporary colonialism: Power projection, resistance and the quest for operational unilateralism. Political Geography, 30(4), 215-224. https://doi.org/10.1016/j.polgeo.2011.04.003

Davis, S., Munger, L.A., \& Legacy, H.J. (2020). Someone else's chain, someone else's road: U.S. military strategy, China's Belt and Road Initiative, and island agency in the Pacific. Island Studies Journal, 15(2), 13-36. https://doi.org/10.24043/isj.104

DeLoughrey, E. (2001). "The litany of islands, the rosary of archipelagoes": Caribbean and Pacific archipelagraphy. ARIEL: A Review of International English Literature, 32(1), 21-51.

Dijkink, G. (1996). National identity and geopolitical visions: maps of pride and pain. Routledge.

Dittmer, J. (2010). Popular culture, geopolitics, and identity. Rowman and Littlefield. 
Favole, A., \& Giordana, L. (2018). Islands of islands: Responses to the centre-periphery fractal model in East Futuna (Wallis and Futuna) and the Belep Islands (New Caledonia). Island Studies Journal, 13(1), 209-222. https://doi.org/10.24043/isj.42

Grohse, I.P. (2013). From asset in war to asset in diplomacy: Orkney in the Medieval realm in Norway. Island Studies Journal, 8(2), 255-268.

Grydehøj, A. (2019). Critical approaches to island geography. Area, 52(1), 2-5. https://doi.org/10.1111/area.12546

Grydehøj, A., \& Casagrande, M. (2019). Islands of connectivity: Archiplelago relationality and transport infrastructure in Venice lagoon. Area, 52(1), 56-64. https://doi.org/10.1111/area.12529

Grydehøj, A., \& Hayward, P. (2014). Social and economic effects of spatial distribution in island communities: Comparing the Isles of Scilly and Isle of Wight, UK. Journal of Marine and Island Cultures, 3(1), 9-19. https://doi.org/10.1016/j.imic.2014.03.002

Hague, A. (1990). Destroyers for Great Britain: a history of 50 town class ships transferred from the United States to Great Britain in 1940. Naval Institute Press.

Hall, H.D. (1955). North American supply. HMSO and Longmans, Green \& Co.

Heinrichs, W. (1988). Threshold of war: Franklin D. Roosevelt and American entry into World War II. Oxford University Press. https://doi.org/10.1086/ahr/95.1.293-a

High, S. (2009). Base colonies in the Western Hemisphere, 1940-1967. Palgrave Macmillan.

Kang, P. (2011). China's island frontier: Geographical ideas on the continent-based Nationalist narratives on Taiwan. Island Studies Journal, 6(1), 29-44.

Kimball, W.F. (2013). Introduction. Journal of Transatlantic Studies, 11(3), 231-233.

Kimball, W.F. (1997). Forged in war: Roosevelt, Churchill, and the Second World War. Ivan R. Dee. https://doi.org/10.2307/20048308

Kluckhohn, F.L. (1941, November 30). We add Dutch Guiana to vast chain of bases. The New York Times, E5.

Kluckhohn, F.L. (1940a, July 14). Atlantic islands a defense puzzle. The New York Times, 56.

Kluckhohn, F.L. (1940b, September 4). Line of 4,500 miles. The New York Times, 1.

Lee, S.J. (1994). Aspects of British Political History, 1815-1914. Routledge.

Matloff, M., \& Snell, E.M. (1999). Strategic planning for coalition warfare, 1941-1942. Center of Military History, United States Army. (Original work published 1953)

Miller Center. (2019). October 5, 1937: Quarantine Speech. Presidential Speeches: Franklin D. Roosevelt Presidency. Miller Center, University of Virginia. https://millercenter.org/thepresidency/presidential-speeches/october-5-1937-quarantine-speech

Morton, L. (1949). American and Allied strategy in the Far East. Military Review, XXIX, 2239.

Mountz, A. (2015). Political geography II: Islands and archipelagos. Progress in Human Geography, 39(5), 636-646. https://doi.org/10.1177/0309132514560958

The New York Times. (1941, April 3). British hope for ships: Think giving of seized craft would be act of justice. The New York Times, 8.

The New York Times. (1940a, September 4). Comment by press on British accord. The New York Times, 13. 
The New York Times. (1940b, August 17). U.S. is negotiating for British bases, plan with Canada: British possessions where United States may obtain naval bases. The New York Times, 1.

Petzold, J., \& Ratter, B.M.W. (2019). More than just SIDS: local solutions for global problems on small islands. Island Studies Journal, 14(1), 3-8. https://doi.org/10.24043/isj.77

Pöllath, M. (2018). Revisiting island decolonization: The pursuit of self-government in Pacific island polities under US hegemony. Island Studies Journal, 13(1), 235-250. https://doi.org/10.24043/isj.46

Pugh, J. (2018). Relationality and island studies in the Anthropocene. Island Studies Journal, 13(2), 93-110. https://doi.org/10.24043/isj.48

Pugh, J. (2016). The relational turn in island geographies: bringing together island, sea and ship relations and the case of the Landship. Social and Cultural Geography, 17(8), 10401059. https://doi.org/10.1080/14649365.2016.1147064

Pugh, J. (2013). Island movements: Thinking with the Archipelago. Island Studies Journal, $8(1), 9-24$.

Reston, J.B. (1941, February 26). Bases pacts give US large powers in British Areas. The New York Times, 1, 9.

Shell, M. (2014). Islandology: geography, rhetoric, politics. Stanford University Press.

Shogan, R. (1995). Hard bargain: How FDR twisted Churchill's arm, evaded the law, and changed the role of the American presidency. Westview. https://doi.org/10.1086/ahr/101.5.1648

Steinberg, P. (2001). The social construction of the ocean. Cambridge University Press.

Steinberg, P., \& Peters, K. (2015). Wet ontologies, fluid spaces: Giving depth to volume through oceanic-thinking. Environment and Planning D: Society and Space, 33(2), 247264. https://doi.org/10.1068/d14148p

Stirling, Y., Jr. (1940, August 23). Bases 'vital need' of American navy. The New York Times, 4.

Stoler, M.A. (2013). From World War II to Cold War: The emergence and development of George C. Marshall's Transatlantic worldview and policies, 1939-1951. Journal of Transatlantic Studies, 11(3), 308-318. https://doi.org/10.1080/14794012.2013.814394

Stratford, E. (2013). The idea of the archipelago: Contemplating island relations. Island Studies Journal, 8(1), 3-8.

Stratford, E. (2003). Flows and boundaries: Small island discourses and the challenge of sustainability, community and local environments. Local Environment, 8(5), 495-499. https://doi.org/10.1080/1354983032000143653

Stratford, E., Baldacchino, G., McMahon, E., Farbotko, C., \& Harwood, A. (2011). Envisioning the archipelago. Island Studies Journal, 6(2), 113-130.

Till, G. ( 2013). Seapower: A guide for the twenty-first century. Routledge.

US Department of Defense. (2019, May 3). Assistant Secretary of Defense for Indo-Pacific Security Affairs Schriver Press Briefing on the 2019 Report on Military and Security Developments in China. https://www.defense.gov/Newsroom/Transcripts/Transcript/Article/1837011/assista nt-secretary-of-defense-for-indo-pacific-security-affairs-schriver-press/

Waldo, F. (1943). Our island hemisphere. Foreign Affairs, 21(3), 513-523. 
Watson, M.S. (1950). Chief of Staff: Prewar plans and preparations. Historical Division, Department of the Army.

Weaver-Hightower, R. (2007). Empire islands: Castaways, cannibals, and fantasies of conquest. University of Minnesota Press.

Whitham, C. (2013). The thin end of the wedge: The British Foreign Office, the West Indies and avoiding the Destroyers for Bases Deal, 1938-1940. Journal of Transatlantic Studies, 11(3), 234-248. https://doi.org/10.1080/14794012.2013.814382 